\title{
Local Government Responses to HIV and AIDS in the Border Areas: a Case Study of Batam ${ }^{1}$
}

\author{
Augustina Situmorang and Sri Sunarti Purwaningsih \\ Research Centre for Population \\ Indonesian Institute of Sciences
}

\section{Introduction}

Improving the welfare of the people who live in the border areas has been a concern of the Indonesian government for the past few years. Compared with other areas, most of the border areas are relatively less developed, especially in terms of human resources development. Rencana Pembangunan Jangka Menengah/RPJM 2005-2009 [National Development Plan of 2005-2009] noted the shift of development priorities in the border areas from security approach to the prosperity approach.

One of the key indicators of social welfare is health, particularly reproductive health. This term covers maternal and child health, family planning, adolescent services, abortion, and the prevention and treatment of sexually transmitted infections (STI), which include HIV and AIDS. Previous studies (Situmorang, 2006; 2007) indicated that STIs (including HIV and AIDS) are one of the emerging health problems in the border areas of Indonesia. Data show that incident rates of HIV and AIDS in these provinces are higher than in other provinces and higher than the national rates (see Diagram 1).

The high rates of STI, HIV and AIDS in the border areas are influenced by the demographic characteristics of these areas. Border areas are often

1 This summary is based on research conducted by Augustina Situmorang, Sri Sunarti Purwaningsih, Widayatun and Zaenal Fatoni of the Research Centre for Population, Indonesian Institute of Sciences. 
considered as transit places for emigrants and immigrants. Skelton (cited by Hugo, 2001: 37) noted that population mobility may put people in situations of high risk in relation to STIs (including HIV and AIDS); this applies especially to transients, that is, to those who intend to move on. This is because the transients are less likely to have their families with them. Non-permanent migrants and people in transition, who are away from their families and communities, where social and sexual norms are prescribed and followed, may take risks and engage in activities they would not engage in at home, including casual sexual encounters.

Apart from being transit places, border areas are often a destination used by people trafficking chains. Darwin et al. (2003: 253) noted that many young women from various parts of Indonesia who intended to, and were promised, work in Malaysia, ended up working in Batam and surrounding areas as sex workers, serving Singaporean and Malaysian sex tourists. Border areas, such as Batam, are also considered to be centres of industrial development by multinational companies. Thus, many young people come to such places for jobs as labourers in various factories. The highly mobile population, along with industrial development, to some extent has encouraged the growth of various places of entertainment and of sex-related industries. This, then, is a reason why people in border areas are more vulnerable to the spread of STIs, including HIV and AIDS. To make the matter worse, migrants and transient people are often neglected or overlooked in government health policies and programs (UNAIDS, 2001).

Many studies have been done to measure government responses in combating the HIV and AIDS epidemic, especially in countries where the prevalence of these infections is extremely high (UNAIDS, 2005; 2006; 2007). These studies, in the main, have been funded by international agencies such as UNAIDS, UNDP and WHO. The studies use various indicators that have been agreed internationally to ensure statistical consistency and to enable valid comparisons. Numerous guidelines have been produced and technical assistance given, especially by UNAIDS (a United Nations body, which specifically focuses on HIV and AIDS) to help governments respond to the spread of these infections that 
derive from local contacts. UNAIDS, for example, has endorsed the implementation of 'Three Ones' (one national AIDS framework, one national AIDS authority, and one system for monitoring and evaluation) as a principle guideline for improving national responses to these epidemics (UNAIDS, 2005). Other UN agencies, such as UNDP and the World Bank, have also produced guidelines to assist local governments to respond to HIV and AIDS. The guidelines include five key elements to achieve the expected responses: leadership and team building, understanding the local situation, developing a local government HIV/ AIDS response strategy, implementing the local government HIV/ AIDS response strategy, and monitoring and evaluation (UNDP and the World Bank, undated). These guidelines and the technical assistance were aimed especially at monitoring the extent of the implementation of the 6th goal of the Millennium Development Goals (MDG), which were established in 2000 and the implementation of the Commitment Declaration and the Political Declaration which were ratified by most UN member states in 2001 and 2006.

In Indonesia, numerous studies of HIV and AIDS have been conducted by government institutions (Departemen Hukum dan Hak Asasi Manusia RI, 2007; Departemen Kesehatan RI, 2007) and independent institutions such as the National Commission on AIDS Eradication (KPAN), research institutes and universities (Isna, 2005; KPAN, 2008). The studies focused on various aspects of HIV and AIDS including prevention and treatment of people living with these illnesses (care, treatment and support), data and information (estimations and behaviour surveillance) and social aspects (stigma, discrimination and controversial issues). Over the last few years, there have also been studies of local government policies and the implementation of HIV and AIDS programs. Nevertheless, comprehensive studies that examined local government responses to the specific conditions surrounding outbreaks of STIs were limited. For example, despite the high incidence rates of HIV and AIDS in the border areas of Indonesia, there is no study yet exploring the links between this epidemic and the social and economic conditions in border areas and government responses. 
To bridge the gap, this study examines local government responses to HIV and AIDS in the border areas, especially in the city of Batam, Riau Islands Province. The framework utilised in this study was modified from Local government responses to HIV/AIDS; a handbook, which was developed by the Alliance of Mayors' Initiative for Community Action on AIDS at the Local Level (AMICAALL). Nevertheless, this summary limits its focus to describing the knowledge and views of local authorities, including government officers and members of local parliaments, regarding HIV and AIDS issues in Batam. The government's policy, strategy and programs are also discussed, as well as non-government organisation (NGO) programs related to HIV and AIDS in Batam. The information for the study is mostly derived from open-ended interviews and focus group discussions with various respondents from government institutions, NGOs, members of the local parliament, as well as private institutions that work with HIV and AIDS in Batam and in Jakarta. Fieldwork in Batam was conducted for two weeks in April and May 2008.

\section{HIV and AIDS in the Border Areas}

Up to June 2008, the prevalence of AIDS cases in Indonesia was 5.59 per 100000 of population. Interestingly, four of the ten provinces with the highest AIDS incident rates were provinces that border neighbouring countries; namely, Papua, Riau Islands (Kepri), West Kalimantan (Kalbar) and North Sulawesi (Sulut) (see Diagram 1). Riau Islands Province was in the fourth rank, with an AIDS prevalence rate of 20.5 per 100000 . This means that for every 100000 people in this province, approximately 21 people were infected with AIDS. This rate was four times higher than the national average. 


\section{Diagram 1:}

Ten provinces with the highest AIDS prevalence in Indonesia (Data to June 2008)

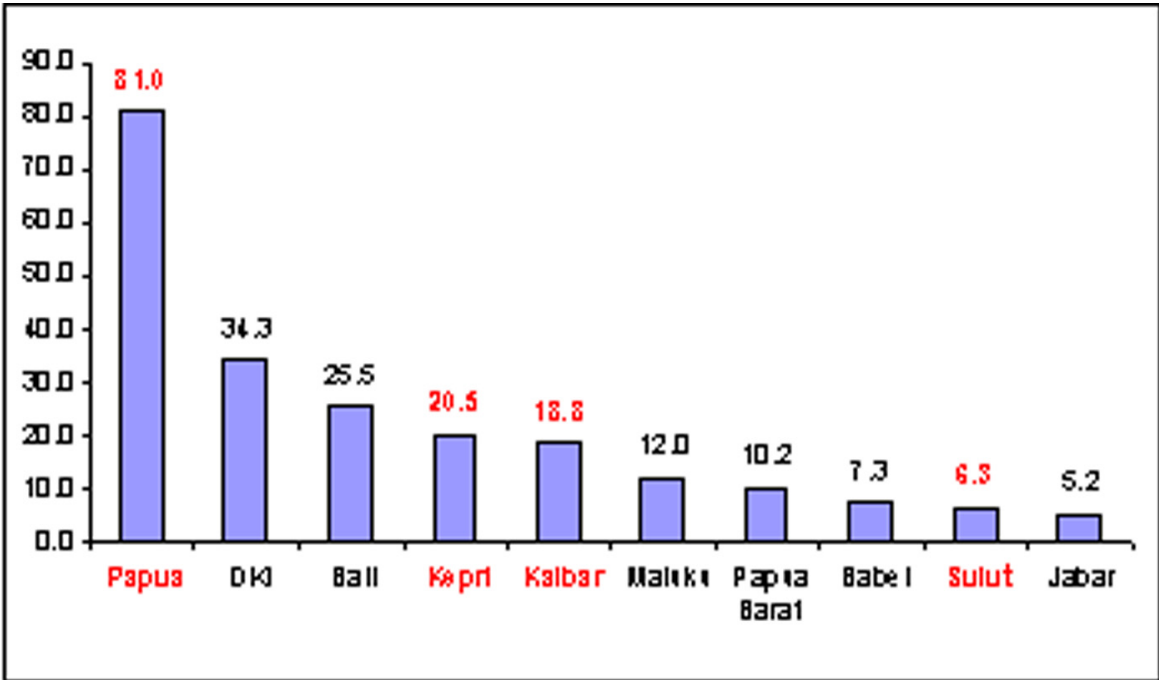

Source: DitJen PPM dan PL, Depkes RI, 2008

Riau Islands Province, on the border of Indonesia, Singapore and Malaysia, comprises 1248 big and small islands, and 96 per cent of the province is coastal. Its geographical position has caused the high population mobility for job seekers or for those who are in transit before entering Singapore or Malaysia (documented and non-documented migrants). Some of the non-documented migrants, who have been repatriated to Indonesia through the international ports in Tanjung Pinang or Batam, remain in Batam permanently and work in various sectors, mostly entertainment and leisure industries (including sex industries).

Since 1992, of the cities and regencies in Riau Islands Province, the highest incidence of HIV and AIDS cases is in Batam. The first HIV case was a female sex worker who worked in the Mat Belanda brothel. Since then, HIV and AIDS have spread to other brothels, such as Samyong, Bukit Girang and Tanjung Sengkuang. The number of cases then increased significantly up to 2007 ; the highest increase occurred 
between 2004 and 2006, from 277 cases to 738 . From 1992 to 2000, the additional new HIV cases range from 8 to 20 every year (see Diagram 2). However since 2001, AIDS cases increased rapidly to more than 25 cases every year. Up to 2007, there were 979 HIV cases found in this city. In line with the incidence of HIV, the cases of AIDS in Batam have also been increasing over the past five years. Diagram 3 shows that in 2000 there were only nine cases of AIDS in Batam, then it increased to 262 cases in 2007.

\section{Diagram 2}

HIV cumulative cases reported in Batam City (Data to 2007)

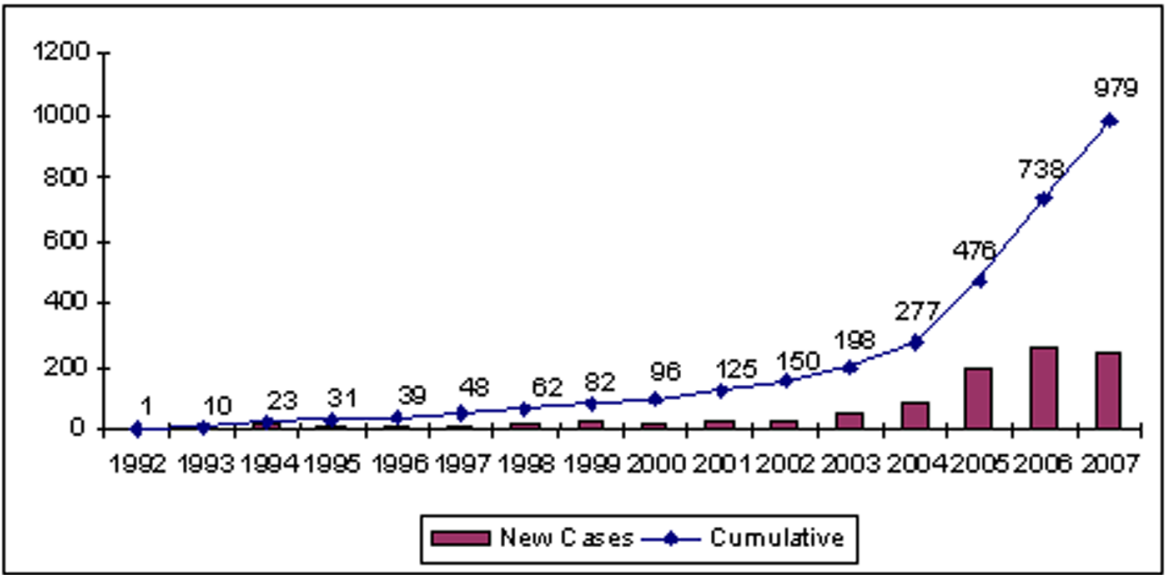

Source: Dinas Kesehatan Kota Batam, 2008 


\section{Diagram 3}

AIDS cumulative cases reported in Batam City (Data to 2007)

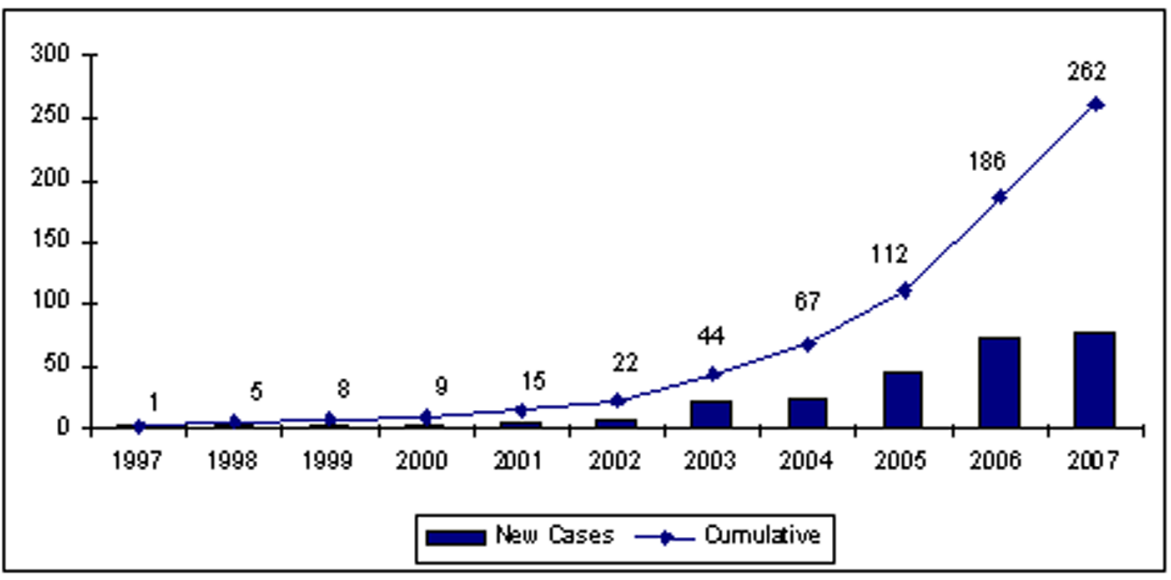

Source: Dinas Kesehatan Kota Batam, 2008

The official data for HIV and AIDS cases in Indonesia mostly are based on reported cases from hospitals and health clinics. Keeping in mind that what we see of an iceberg is not quite all of it, we should be cautious in accepting that the reported number of AIDS and HIV cases is accurate; we can be more confident that the number of cases will be much higher than the statistics suggest. The National AIDS Commission (NAC) predicted that in 2006 the number of HIV at-risk adults in the population in Batam would reach to $69970 .^{2}$

The rapid increase of HIV and AIDS cases in Batam is related to several factors. Among them are risky sexual behaviours especially by migrants, the growth of the sex industry and the increase in human trafficking. The risky sexual practices began to increase in Batam when the industrial areas developed and these industries attracted job seekers

2 The HIV-AIDS-risk population comprises women who are directly or indirectly employed in the comercial sex industry, their clientele, injecting drug users and their spouses, homosexuals and prisoners (KPAN, 2006). 
from other parts of the country. These migrants mostly are young people who have not been sexually active for long. The high numbers of migrants with no families, to some extent, has fuelled the growth of places of entertainment and increased the demand for sexual services, which explains the presence of sex workers around the factories. The high number of male migrants with no family has caused an increase in demand for female entertainers who may be expected to give sexual services. Industrial development in Batam has played an important part in the rise of prostitution, either legally in brothel complexes or illegally, that is, by those who work in the streets, shopping malls and other places. These circumstances have caused a greater likelihood that people in this city will be infected with sexually related infections, including HIV and AIDS.

The development of Batam as an industrial centre has also attracted foreign visitors, especially from Singapore and Malaysia, who visit the nightclubs and other places of nocturnal entertainment. Some visit Batam for business but while they are there they look for entertainment as well. Batam is appealing to such visitors because it is not too distant and the services are cheap. Also appealing to many visitors is the beauty of Batam's natural resources and the surrounding areas, such as Tanjung Pinang and Tanjung Balai Karimun. Usually, the tourists stop off in Batam before going to Tanjung Pinang and Karimun. It is predicted that approximately 5000 tourists from neighbouring countries come to Batam at the weekend.

In addition, the increase in the number of regular visitors from neighbouring countries for work and for pleasure has created a new phenomenon in Batam, that of isteri simpanan (mistress or kept woman). Some of these visitors maintain relationships with local women and treat them as kept women. The kept woman usually lives in a rented house or apartment and is visited by the man at the weekends only. They are also provided with some money weekly or monthly by their man. Compared with their peers, these women are relatively well off. During the week, when they are not with their 'foreign husband' these women often seek younger men to accompany them and may engage in 
sexual relations. These young men are known as brondong or bronces. Several respondents from local NGOs stated that this phenomenon has tended to increase lately. This has contributed to the spread of STIs, including HIV and AIDS, in Batam.

\section{Local authority knowledge related to HIV and AIDS in Batam}

It has been acknowledged globally that HIV and AIDS are not merely health problems but also link to socio-cultural aspects, such as poverty, cultural, traditions and beliefs. Thus, combating HIV and AIDS problems requires a broad, multisector approach. At the national level, various attempts have been made in terms of prevention, treatment and care in response to HIV and AIDS, but these have been inadequate and insufficient. A more systematic approach is needed to improve local capacity to manage and sustain a comprehensive response to the epidemic. Local government plays a key role for such comprehensive responses by creating a more enabling or encouraging environment for community-based initiatives.

In this study, the local government response is examined through the local authority's knowledge of the HIV-AIDS syndrome. The availability of policies and programs related to this epidemic in Batam is also explored. Local government responses to HIV and AIDS outbreaks depend on the knowledge of policy makers including legislators. Adequate knowledge on the part of local authorities about HIV and AIDS in their region will affect government responses to this epidemic. This knowledge includes their understanding of the vulnerability of high risk people, such as migrants and transients. Sufficient knowledge of the circumstances of this epidemic may increase the awareness of the urgent need to deal with this problem.

In general, the local authorities in Batam have inadequate knowledge about HIV and AIDS in their area. In-depth interviews with several respondents from government institutions as well as members of the local parliament revealed that most authorities tend to see HIV and AIDS as a migrant issue. They believe that HIV and AIDS are suffered 
by migrants, not local people, and thus combating this epidemic was not considered a priority and, as a consequence, the availability of funding and programs is limited. Furthermore, HIV and AIDS are considered to be the responsibility of the District Office of Health only. As a result, other sectors and district offices tend to be passive not active in developing policies and programs to combat the spread of HIV and AIDS.

Similar to their counterparts in the government agencies, the legislators' knowledge is limited too, especially members of the Commission IV, which is in charge of people's welfare programs. Most legislators interviewed for this study said they were not aware of the situation in their city regarding HIV and AIDS. Some even said that they had never heard about national or local AIDS commissions in which parliamentarians, national and local, are members. When we mentioned that according to the Batam mayoral decree 87 of 2007, that legislators are to be included as members of local AIDS commission, they looked surprised. One legislator said she thought that the diseases were suffered by commercial sex workers or homosexuals only.

In addition, when asked their opinion about promoting the use of condoms to prevent sexually transmitted infections (STI), most respondents in government agencies and in parliament were hesitant to agree. An official in the District Office of Health (DOH) said that they do not include recommendations to use condoms in their HIV and AIDS program because they are afraid of opposition by religious and adat leaders. Some members of parliament interviewed, believed that promoting condom use is not appropriate for the people of Batam because it is not in line with religious preaching and will encourage people to be promiscuous

The limited background knowledge of HIV and AIDS on the part of local authorities in Batam has affected policies and programs regarding this epidemic. Dealing with HIV-AIDS is not considered to be a program priority. Thus there is no specific budget line in local government funding for this epidemic. In the $\mathrm{DOH}$ budget, for example, funds for an HIV-AIDS prevention program is allocated from the transmitted 
diseases prevention program but the current priorities of that program are combating dengue fever and malaria. Therefore, the funds allocated for health promotion are used mostly for the prevention of these two diseases; very little is for HIV and AIDS.

\section{STI and HIV-AIDS prevention policies and programs}

During the course of this study we found that Batam has few local policies explicitly for the prevention and combating of STIs (including HIV and AIDS) and this is shown by the minimum political commitment and the program's inadequate funding. In line with the Letter of the Ministry of Home Affairs 443.1/990/SJ, dated 16 May 2002, regarding local government support for the national movement to prevent HIVAIDS, Batam City has formed a Local AIDS Commission (LAC). The formation of this commission based on the Mayoral Decision Letter (Surat Keputusan Walikota) of 23 April 2007. An LAC is an institution formed to coordinate local AIDS prevention programs. Considering the complexity of HIV-AIDS problems, an LAC is expected to coordinate health and social aspects as well as counselling people living with AIDS.

Similar to LACs in other Indonesian cities, the Batam LAC involves government and private organisations, NGOs, academicians as well as health professionals. The Batam LAC is headed by the mayor, the daily leader is the vice-mayor and the head of the DOH acts as the executive leader. These appointments were made based on an assumption that the involvement of the mayor as well as the head of government institutions as ex-officio will provide better access and environment for HIV and AIDS-related activities.

Nevertheless, the LAC has yet to contribute to any HIV-AIDS program. In-depth interviews with several respondents revealed that the LAC in Batam City has no clear work agenda. One respondent from the LAC secretariat said, 'until today [May 2008] there has been no meeting that involves all of the LAC committee members'. The mayor has never attended any HIV or AIDS-related activities. In addition, funds that have 
been specifically allocated for LAC activities are very limited; they are not sufficient even for the daily operations of a secretariat. Thus, it is not surprising to find out that there is no regular LAC meetings that would let the members of committees share updated data or information about activities.

Considering the limited funding allocated by the local government, most programs for HIV-AIDS-related issues in Batam were funded by international funding agencies such as Family Health International (FHI) and the Global Fund. Government programs were limited to inspections, and funded by the Ministry of Health $(\mathrm{MOH})$ in collaboration with the DOH of Batam. The inspections are every three months and are especially for those who work in places where there is a high risk of STIs, such as the brothel in Tanjung Uncang. An inspection is limited to data identification with no comprehensive follow up action even though the data indicate that a substantial number of people were infected by HIV or AIDS. The Global Fund, in collaboration with DOH has developed a health clinic in the brothel complex of Tanjung Uncang.

The Family Health International (FHI) organisation has also funded several HIV-AIDS-related programs in Batam. Collaborating with DOH and local NGOs, such as Yayasan Batam Tourism Development Board (YBTDB), FHI funded the development of a special clinic for HIV-AIDS in the Primary Health Center complex in Lubuk Baja, which arranged voluntary counselling and treatment (VCT). The YTBDB has worked on HIV and AIDS-related programs since 2003 and conducted several such programs on outreach and assistance for people living with HIV and AIDS. One current YBTDB program is to make mandatory the introduction of 100 per cent condom use for clients of brothels. The management of the brothel in Tanjung Uncang has agreed to implement the policy that the use of condom is a must for clients. The 100 per cent use of condoms in brothels has been initiated at the provincial level under Riau Islands Provincial law. Nevertheless it has yet to be enforced in Batam. Because there is no specific regulation, the implementation of mandatory use of condoms in the brothels of Batam is limited to those places where specific agreements have been made. As a result, the 
implementation of this regulation is limited to the legal brothels: illegal or unorganised brothels remain unaffected.

Another important local NGO in Batam that deals with HIV and AIDS-related programs is Pembina Asuhan Bunda. This organisation has social awareness programs for schools, youth clubs and youth organisations (the youth of mosques and churches) that relate to all sexually transmitted infections. This program is funded by the UNFPA. Since 2004, Yayasan Pembinaan Asuhan Bunda has run a reproductive health clinic, which gives counselling services and treatment for sexually transmitted diseases; the main target was commercial sex workers who work freelance in pubs and karaoke bars. The clinic is in a very strategic place-the city centre-where most of the commercial sex workers work. Beside the provision of health services for commercial sex workers, this NGO also facilitated socialisation and medical tests every month for female commercial sex workers in the pubs and karaoke bars. For the past few years, Yayasan Pembinaan Asuhan Bunda has expanded its services to cover prisons and to build or organise clinics for VCT and to provide medical assistance for those infected with HIV or AIDS.

The involvement of international funding agencies with HIV-AIDS programs basically aims at stimulating local governments to enable funds for developing policies and programs to combat the spread of these epidemics. Nevertheless, the study found that the local government budgeting for these programs was still limited. Most HIV-AIDS-related programs are still conducted by NGOs that do not have adequate funds and capability. In addition, coordination between government and NGOs as well as among NGOs was weak. There was a tendency among institutions to give priority to their own programs or activities and they were unwilling to share data with others, which then resulted in overlapping programs or activities. Because most HIV-AIDS programs were conducted by NGOs that are limited in terms of funds and human resources, program coverage of HIV-AIDS-related issues in Batam was inadequate. 


\section{Conclusion}

Being a city in the border area that is commonly considered a 'transit place', has put the population of Batam at a higher risk of infection with sexually related diseases, including HIV and AIDS. Living 'temporarily', far from their family and community where social and sexual norms are prescribed and followed, migrants and transient people may be tempted to visit entertainment and other facilities and to engage in unsafe sexual activity. The national data indicated that provinces in the border areas have higher rates of HIV and AIDS than do other provinces. Nevertheless, there are no policies or programs to combat this epidemic that is specific to the demographic characteristics of people in border areas. Despite the high rates of HIV and AIDS infections in Batam, the local authorities have not considered this to be urgent. This is partly because of lack of knowledge on the part of the local authorities of the effect of HIV and AIDS on the health and welfare of the people of Batam. HIV and AIDS were considered to affect migrants but not to affect local people. The misperception among local authorities that HIV and AIDS only infect promiscuous people was still in evidence. In addition, the program to promote the use of condoms to prevent HIV and AIDS was still under debate.

Programs for HIV-AIDS treatment and prevention in Batam depend heavily on international funding agencies and NGOs, which have limited resources, thus the program coverage was limited. To develop and implement comprehensive policies and programs for HIV-AIDS, the local government needs to work hand in hand with the international funding agencies as well as local NGOs. To do this the local government through its LAC should have a comprehensive, strategic plan to deal with HIV-AIDS-related issues, a plan that takes into account specific local circumstances and needs.

\section{References}

Badan Pusat Statistik (BPS) dan Departemen Kesehatan RI. 2005. Situasi perilaku berisiko tertular HIV di Indonesia: hasil SSP tahun 2004-2005. Jakarta: BPS dan Departemen Kesehatan RI. 
BKKBN, Lembaga Demografi FE UI dan UNFPA Jakarta. 2005. Kependudukan dan pembangunan di Indonesia: keterkaitan konsensus International Conference on Population and Development (ICPD) dengan Target Millenium Development Goals (MDGs). Jakarta: UNFPA Jakarta.

Darwin, Muhadjir, Anna Marie Wattie, Siti Ruhaini Dzuhayatin and Susu Eja Yuarsi, 2003. "Traffiking and Sexuality in Indonesia-Malaysia Cross-Border Migration" in Darwin et al. (eds), Living on the Edges: Cross-Border Mobility and Sexual Exploitation In The Greater Southeast Asia Sub-Region, Yogyakarta: Centre for Population and Policy Studies Gadah Mada University.

Departemen Hukum dan Hak Asasi Manusia RI. 2007. Laporan eksekutif Program Penanggulangan HIV/AIDS Lapas/Rutan di Indonesia. Jakarta: Departemen Hukum dan Hak Asasi Manusia.

Departemen Kesehatan RI dan Family Health International (FHI). 2006. Laporan hasil penelitian prevalensi infeksi saluran reproduksi pada wanita penjaja seks di Tanjungpinang, Kepulauan Riau, Indonesia, 2005. Jakarta: Departemen Kesehatan RI dan Family Health International.

Departemen Kesehatan dan UNAIDS. 2002. Sidang Kabinet Sesi Khusus HIV/AIDS Maret 2003. Penanggulangan HIV/AIDS di Indonesia: respon saat inimenangkal ancaman bencana nasional AIDS mendatang. Jakarta: Departemen Kesehatan.

Departemen Kesehatan RI, Kementerian Negara Pemberdayaan Perempuan RI, Departemen Pendidikan Nasional RI, Departemen Sosial RI, Badan Koordinasi Keluarga Berencana Nasional bekerja sama dengan UNFPA. 2005. Kebijakan dan strategi nasional kesehatan reproduksi di Indonesia. Jakarta: Departemen Kesehatan RI.

Departemen Kesehatan RI. 2007. Keputusan menteri kesehatan Republik Indonesia nomor 1197/MENKES/SK/XI/2007 tentang kelompok kerja penanggulangan HIV/AIDS Departemen Kesehatan. Jakarta: Departemen Kesehatan RI.

Departemen Kesehatan RI. 2007. Keputusan menteri kesehatan Republik Indonesia nomor 760/MENKES/SK/VI/2007 tentang penetapan lanjutan rumah sakit rujukan bagi orang dengan HIV/AIDS (ODHA). Jakarta: Departemen Kesehatan RI.

Departemen Tenaga Kerja dan Transmigrasi. 2004. Keputusan menteri tenaga kerja dan transmigrasi Republik Indonesia nomor KEP.68/MEN/IV/2004 tentang pencegahan dan penanggulangan HIV/AIDS di tempat kerja. Jakarta: Kantor ILO Jakarta.

Dinas Sosial Provinsi Kepulauan Riau. 2007. Rencana strategik 2006-2010. Tanjungpinang: Dinas Sosial Provinsi Kepulauan Riau.

Direktorat Kesehatan Komunitas, Departemen Kesehatan RI. tanpa tahun. Pelayanan Kesehatan Daerah Terpencil dan Perbatasan (makalah singkat). Jakarta: Direktorat Kesehatan Komunitas Departemen Kesehatan RI.

Ditjen, PP and PL, Departemen Kesehatan RI. 2008. Laporan statistik kasus HIV/ AIDS di Indonesia (Dilapor sampai dengan Juni 2008). Jakarta: Ditjen PP \& 
PL Departemen Kesehatan RI.

Health Economics and HIV/AIDS Research Division, University of Natal and USAID The Policy Project. 2001. HIV/AIDS toolkit for local government. KwazuluNatal: USAID.

Hugo, Graeme. 2001. Population mobility and HIV/AIDS in Indonesia. Jakarta: International Labour Office.

Isna, Alizar; Solahudin Kusumanegara dan Nurlaela. 2005. Penanggulangan PMS dan HIV/AIDS pada Era Otonomi Daerah. Seri Laporan Nomor 148. Yogyakarta: Ford Foundation dan Pusat Studi Kependudukan dan Kebijakan UGM.

Kementerian Koordinator Bidang Kesejahteraan Rakyat dan Komisi Penanggulangan

AIDS Nasional. 2003. Strategi nasional penanggulangan HIV/AIDS 20032007. Jakarta: Kementerian Koordinator Bidang Kesejahteraan Rakyat dan Komisi Penanggulangan AIDS Nasional.

Komisi Penanggulangan AIDS. 2005. Country reportmengenai tindak lanjut deklarasi komitmen HIVIAIDS (UNGASS) periode pelaporan 2003-2004. Jakarta: Komisi Penanggulangan AIDS.

Komisi Penanggulangan AIDS (NAC). 2005. The Indonesian Partnership Fund for HIV/AIDS. Jakarta: Komisi Penanggulangan AIDS (NAC).

Komisi Penanggulangan AIDS. 2006. Laporan nasional kegiatan estimasi populasi dewasa rawan terinfeksi HIV tahun 2006. Jakarta: Departemen Kesehatan RI dan Komisi Penanggulangan AIDS.

Komisi Penanggulangan AIDS. 2007. Strategi nasional penanggulangan HIV/AIDS 2007-2010. Jakarta: Komisi Penanggulangan AIDS.

Komisi PenanggulanganAIDS Nasional. 2007. Rencana aksinasional penanggulangan

HIV/AIDS di Indonesia 2007-2010. Jakarta: Komisi Penanggulangan AIDS Nasional.

Ministry of Health Indonesia. 2007. Review of the health sector response to HIV/AIDS in Indonesia 2007. New Delhi: World Health Organization, Regional Office for South-East Asia.

National AIDS Comission-Republic of Indonesia. 2008. Country report on the follow up to the Declaration of Commitment on HIV/AIDS. UNGASS reporting period 2006-2007. Jakarta: National AIDS Comission.

Pemerintah Kota Batam. 2007. Keputusan Walikota Batam Nomor KPTS.86/HK/ IV/2007 tentang Pembentukan Pengurus Komisi Penanggulangan AIDS (KPA) Kota Batam. Jakarta: Pemerintah Kota Batam.

Pemerintah Provinsi Kepulauan Riau. 2007. Peraturan daerah Provinsi Kepulauan Riau nomor 12 tahun 2007 tentang penghapusan perdagangan perempuan dan anak (trafiking). Tanjungpinang: Pemberdayaan Perempuan-Sekretariat Daerah Provinsi Kepulauan Riau.

Pemerintah Provinsi Kepulauan Riau. 2007. Peraturan daerah Provinsi Kepulauan Riau nomor 15 tahun 2007 tentang pencegahan dan penanggulangan HIVI 
AIDS dan IMS di Provinsi Kepulauan Riau. Tanjungpinang: Biro Hukum dan Organisasi-Sekretariat Daerah Provinsi Kepulauan Riau.

Pemerintah Republik Indonesia. 2006. Peraturan Presiden Republik Indonesia nomor

75 tahun 2006 tentang Komisi Penanggulangan AIDS Nasional. Jakarta: Pemerintah Republik Indonesia.

Purwaningsih, Sri Sunarti; Augustina Situmorang, Widayatun, Zainal Fatoni dan Yuly Astuti. 2006. Kondisi kesehatan reproduksi di wilayah perbatasan: kasus Kabupaten Sanggau dan Kota Batam. Laporan Penelitian PPK-LIPI. Jakarta: PPK-LIPI.

Rumah Sakit (RS) Budi Kemuliaan Batam. 2007. Data kasus HIV/AIDS di RS Budi Kemuliaan Kota Batam. Batam: RS Budi Kemuliaan.

Situmorang, Augustina; Sri Sunarti Purwaningsih, Widayatun, Zainal Fatoni and Yuly Astuti. 2007. Kondisi kesehatan reproduksi di wilayah perbatasan: fenomena IMS termasuk HIVIAIDS. Laporan Penelitian PPK-LIPI. Jakarta: PPK-LIPI.

World Bank, UNDP, AMICAAL, Urban Management Programme and Cities Alliance. 2003. Local Government Responses to HIV AIDS: A handbook to support local government authorities in adressing HIV/AIDS at the municipal level. Washington DC: World Bank Group.

UNAIDS. 2001. Global strategy framework on HIV/AIDS. Geneva: UNAIDS.

UNAIDS. 2005. The Global Task Team, a pathway to implement the 'Three Ones'opportunities for scaling up the response to HIV at country level (guidance note). Geneva: UNAIDS.

UNAIDS. 2005. The 'Three Ones' in action: where we are and where we go from here. Geneva: UNAIDS.

UNAIDS. 2006. Setting national targets for moving towards universal access: a working document. Geneva: UNAIDS.

UNAIDS. 2008. Report on the Global AIDS Epidemic. Geneva: UNAIDS.

Wagner, Lola and Danny Irawan Yatim. 1997. Seksualitas di Pulau Batam (Suatu Studi Antropologi). Jakarta: Pustaka Sinar Harapan bekerja sama dengan Yayasan Perspective dan the Ford Foundation.

Yayasan Spiritia. tanpa tahun. Sejarah HIV di Indonesia. Dikutip dari http://spiritia. or.id/. 